\title{
The Green Innovation of Business Model in Im- proving SMEs Business of Smoked Fish in North Sulawesi, Indonesia
}

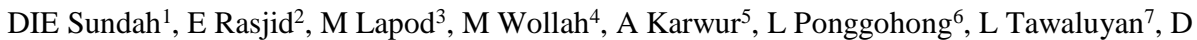

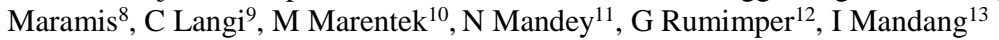 \\ \{dvogessundah@yahoo.com $\left.{ }^{1}\right\}$ \\ Politeknik Negeri Manado, Indonesia
}

\begin{abstract}
The product of smoked fish commonly called "Ikang Cakalang Fufu" is a primer product of North Sulawesi Province that has a distinctive characteristic and becomes one of the food products known by the people of Indonesia. The selling price of smoked fish products is very expensive compared to the unprocessed fish. This is caused by the processing of smoked fish that traditionally due to use the large of space and time consumed. Consequently, production cost becomes too high. This is a descriptive study with entrepreneurs who have smoked fish business. We analyzed the existing SMEs of Lastari and Laiya business and implemented a business model and green technology for the production process. The purpose of this community service activity for SME is to set the production system using green technology approach, to increase efficiency and the quantity as well as the quality of products and packaging. The methods used are the provision of green technology equipment to improve the efficiency of the production process and improve time efficiency in production as well as increase SME's revenue.
\end{abstract}

Keywords: SMEs, Green Technology, Green Business

\section{Introduction}

The Smoke Fish Product famously known as "Ikang Cakalang Fufu" is a primer product of North Sulawesi Province in which it has extra ordinary type of fish of the region and has become one of the types of food products known by the people of Indonesia. Furthermore, this type of product is often used as a souvenir for tourists who are visiting North Sulawesi. Several other types of food in North Sulawesi Province which using smoked fish products mainly provided in the local restaurants. Therefore, this smoked fish product is one of the most wanted in traditional markets, supermarkets, and even at souvenir shops. Moreover, this smoked fish product is often found in certain restaurants outside the North Sulawesi Province where traditional meals are offered. 
The selling price of this smoked fish product is very expensive compared to the unprocessed one. This is due to the process of smoked fish which traditionally requires lots of time and space. The aims of community service activities are to provide solutions to priority issues faced by Lastari SMEs in order to improve quality of product and packaging, introduce the value of green technology products, increase quantity and volume of sales through exports of green smoked fish products for the domestic market. Some of the problems faced by Lastari SMEs are managed in the activities of the Development Program of Regional Primer Products, namely:

1. The unavailability of green technology equipment

2. The lack of cool storage equipment

3. The process of fish production is inefficient

4. The layout of equipment and supporting materials for the production process is not well organized, neat and clean.

5. The unavailability standard of quality assurance in the production process.

6. The production process of fish production has not been arranged in a hygienic and neat.

7. The unavailability of quality assurance

8. The unavailability of safety, healthy and high quality of packaging product technology

9. The production of smoked fish is not competitive and does not have a green value of the product.

10. The marketing system has not been maximized because of the distribution of smoked fish products are only distributed to the surrounding community of Lastari, although the quality of smoked fish products has been known by certain communities outside the area.

11. The unavailability of taxes and have never paid sales tax.

12. The unavailability of a business license.

13. The unavailability product's license which is called P-IRT.

14. The unavailability of promotion to support sales of the product.

15. Have never received training on the process and quality of hygienic smoked fish products.

16. The unavailability of product storage.

\section{Methodology}

\subsection{The Implementation of green technology to improve the efficiency of the pro-} duction process and the place arrangement of smoked fish production

Previously, Lastari SMEs has not paid attention to the place of smoked fish production, specifically concerning the cleanliness and tidiness aspects. Lastari SMEs was using traditional technology with regard to inefficiency and pollution. The green technology of smoked fish fumigation offered solutions to reduce pollution, improve time efficiency in the fumigation process, as well as produce liquid smoke that can be used to increase SMEs income. The prototype of green technology in producing smoked fish was introduced in the [1] and [2].

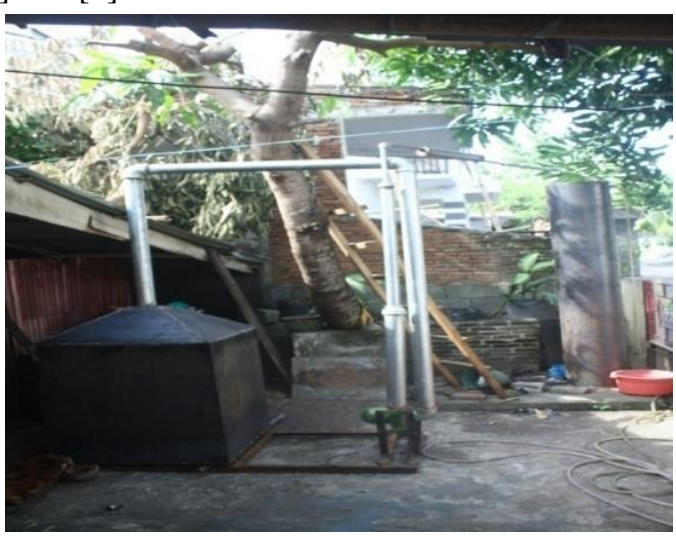


Figure 1. Prototype of Green-Tech

\subsection{Implementation of business model in improving the quality of product and packaging}

Lastari SMEs business model was still traditional, and therefore, it has not been able to increase production capacity and break through the Domestic market. The business model implemented with Lastari SMEs has begun with structuring a green technology of production system, establishing value for green smoked fish products, as well as improving the quality of products and packaging. The results of research on 44 smoked fish (Cakalang Fufu) business entrepreneurs in Manado City, North Minahasa Regency, and Bitung City in 2016 and 2017 found a smoked fish business model. This business model is implemented in community service activities in the Development Program of Regional Primer Product or is called as PPPUD which can be shown in Figure 2.2 as follows:

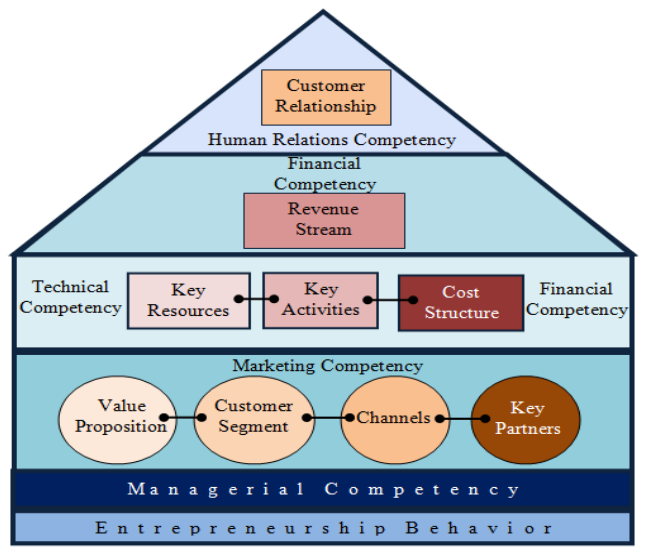

Figure 2. Business Model of Smoked Fish

Figure 2 shows smoked fish business model of the result research in 2016 and 2017 from 44 smoked fish entrepreneurs in Manado City, North Minahasa Regency, and Bitung City. Most of these entrepreneurs have demonstrated entrepreneurial working behaviours in implementing of their business activities. The entrepreneurial behaviors are 
discipline and honest, diligent, cooperation, creative, risk-taking and thrifty, and innovative [3] [4]. Courses of creativity and method of instruction and evaluations were raised for curriculum development [5]. It was also found that the greater the education of the manager, the more the manager is likely to adopt creative and innovative activities [6]. This entrepreneurial behavior has to be completed with the entrepreneurial competencies [7]. However, it was also found that entrepreneurial education has small correlation with the entrepreneurial intentions [8]. Moreover, managerial competencies have been well implemented by these entrepreneurs. It also found that technological skill, marketing skill, managerial skill, human resources skill, and accounting and financial skill are needed by the entrepreneurs [9].

The implementation of the results of the research on smoked fish business models in development program of regional primer product or which is called PPPUD was began with strengthening Marketing Competencies and Technical Competencies. It aims to improve the quality of products and packaging. Therefore, the implementation of this green smoked fish business model began by forming and introducing the value of green products, improving product quality and packaging, improving efficiency in the process of production, and increasing sales as well as revenue volume of Lastari SMEs.

\section{Result and Discussion}

Lastari SMEs has been chosen as a pilot project in Kaima Village, Kauditan District, North Minahasa Regency. The business strategies in the activities of Development Program of Regional Primer Product which is called PPPUD are as follows:

3.1. Provision of green technology to increase the efficiency of the production process and the arrangement of production place

The research findings by Sundah, Tawalujan, and Maramis, 2016 and 2017 show that green technology equipment can provide solutions to reduce pollution and increase efficiency in process of production. The green technology is carried out in accordance with the system of production used by Lastari SME. Thus, it does not change the pattern / habit in the process production of Lastari SMEs.The research findings by Sundah, Tawalujan, and Maramis, 2016 and 2017 shown that green technology equipment can provide solutions to reduce pollution and increase efficiency in the process of production. The green technology is carried out in accordance with the system of production used by Lastari SMEs. Thus, it does not change the pattern/habit in the process production of Lastari SMEs.

Figure 3.1 shows the production capacity accommodate 10 skipjack/per production activity with a fish weight of 10-12 kg / 1 fish, while the small size of fish weighs 5-6 $\mathrm{kg} / 1$ fish as many as 12 fishes. Figure 3.2 shows an increase in production capacity to 18 fish / production activities with a size of fish weight, namely: $10-12 \mathrm{~kg} / 1 \mathrm{fish}$, while the size of fish weighing 5-6 kg / 1 fish as many as 20 fish fumigation. Moreover, the time spent in the production process becomes more efficient where previously the smoking process carried out for 3 - 4 hours, and now it can be processed for 2 hours. 


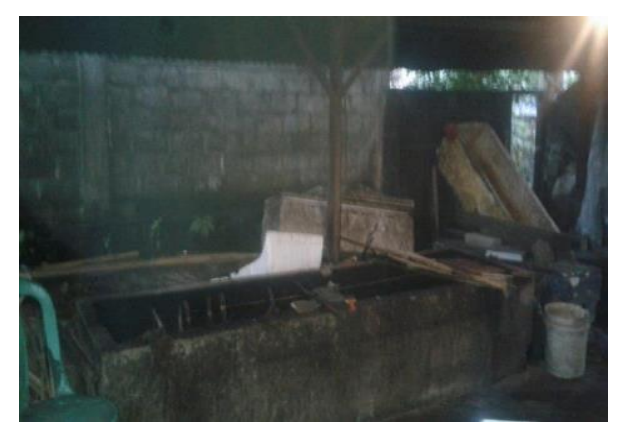

Figure 3. Place of smoked fish production before PPPUD activities

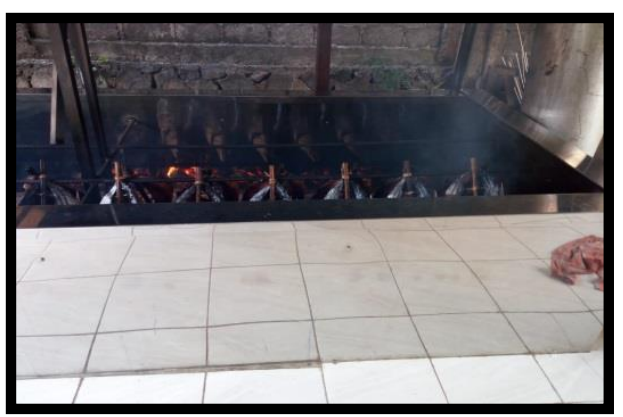

Figure 4. Improvement of Production Capacity

\subsection{Arrangement of production place (fish cleaning) at Lastari SMEs}

Lastari SMEs has not paid attention to the place of production process and therefore, it has not been arranged clean and neat. Community service activities with the PPPUD scheme have provided solutions, especially in the arrangement of a cleaner and tidy place for the production process (fish cleaning). The production place become cleaner and tidy as follows:
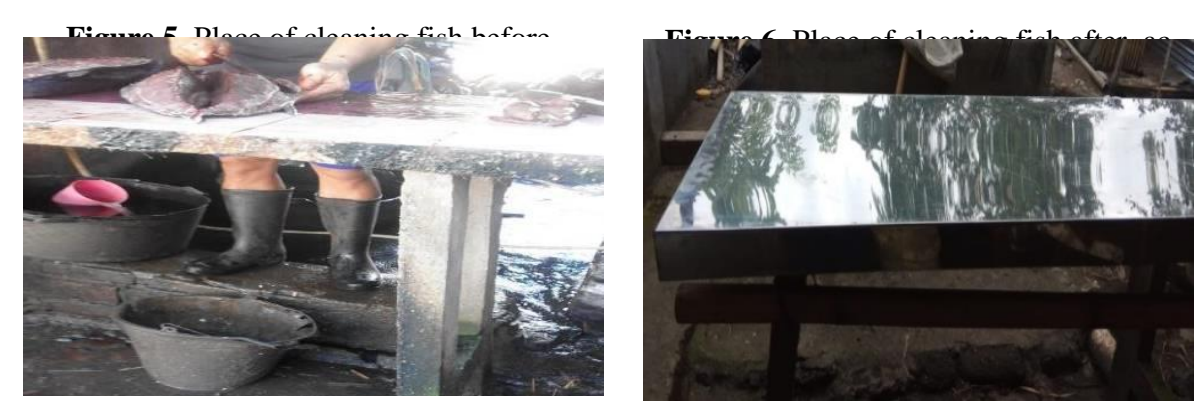

\subsection{Improving Storage Capacity of Raw Material and Smoked Fish Product} (Cakalang Fufu)

Figure 5 and Figure 7 show the limited capacity of storage for raw materials and product of smoked fish (Cakalang Fufu). Lastari SMEs and laiya SMEs with PPPUD

activities provided 1 Freezer and 1 Showcase for Lastari SMEs and 1 Freezer for Laiya SMEs. These activities can be shown in the following Figures: 

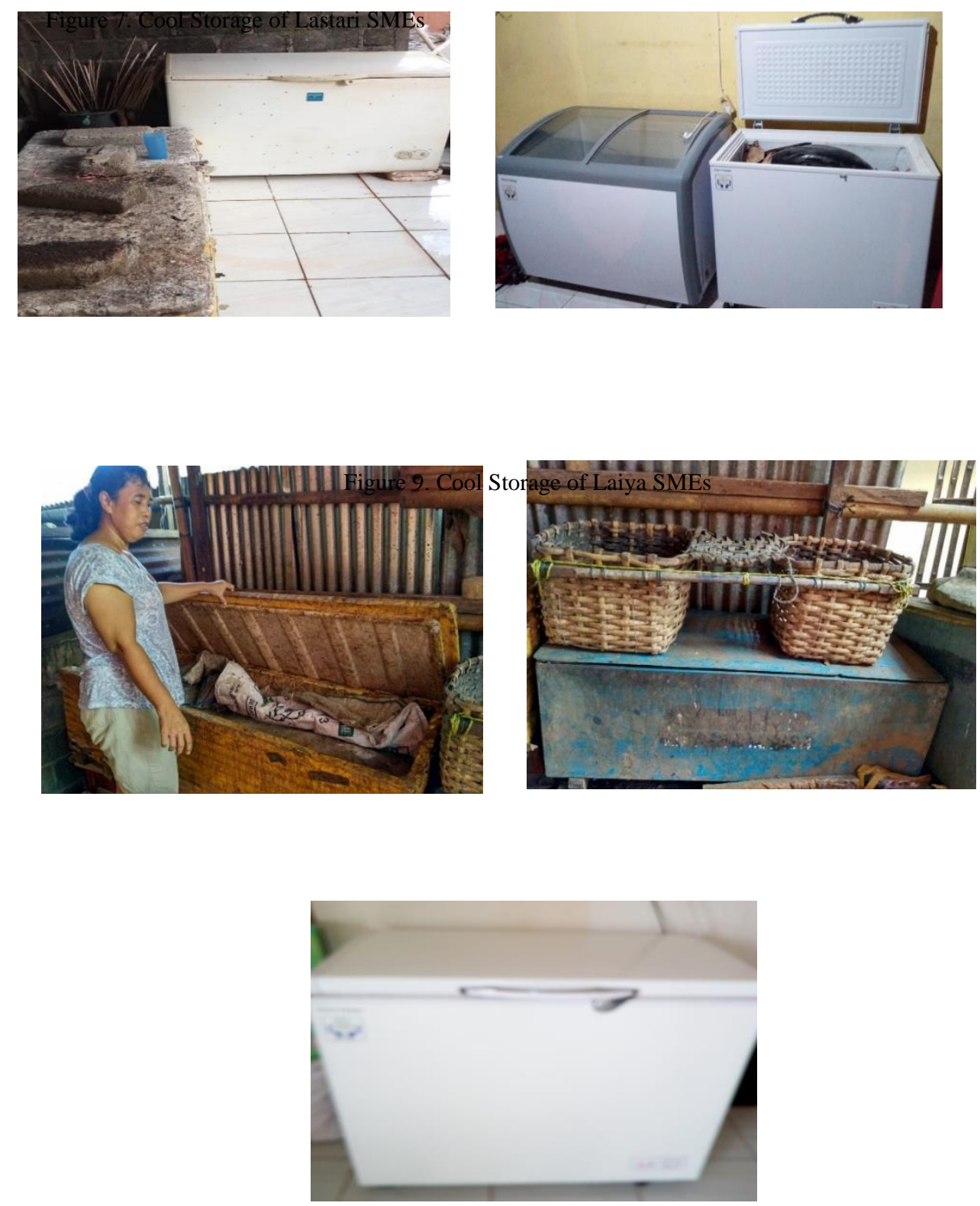

Figure 10. Improvement of Storage Capacity of Laiya SMEs

\subsection{The Implementation of green smoked fish business model at Lastari SMEs} The business model implemented by SMEs Lastari is a traditional business or family business.After many years it has not been able to increase production capacity and consequently it could not penetrate the Domestic market. However, it was proved that self- 
fulfillment, knowledge, skills and experience, including relationship to business partner are all important factors to develop women entrepreneurs [10]. The arrangement of the business model of which carried out together with Lastari SMEs begin with structuring a green technology production system and improving the quality of products and packaging.

These strategies are related to the community, competitive advantage and environmental need of SMEs Smoked fish business. Therefore, a relationship among the strategic factor, motivational factor, personality factor, communicative factor in achieving entrepreneurial leadership of business is needed [11].The implementation of business model is carried out by developing business strategies on Technical Competencies and Marketing Competencies as follows:

3.4.1. Business License for Lastari SMEs, Kaima Village and Laiya SMEs, Kauditan I Village, KauditanDistric, North Minahasa Regency.

Together with Lastari SMEs and Laiya SMEs, to make business licenses and tax license in implementing business activities of Smoked Fish.

3.4.2. Product License or P-IRT (Pangan-IndustriRumahTangga) for Lastari SMEs, Kaima Village, KauditanDistric, North Minahasa Regency

One of the strategies in business development and the introduction of the green value for Lastari SMEs are: the provision of green technology of fish fumigation, provision of product assurance, arrangement of production place and procedures for the implementation of production processes. Some aspect that supported to have a product license (P-IRT) are:

- Business License from Village of Kaima authority

- Business License from District of Kauditan Authority

- Health Certificate from Kauditan District Health Center, North Minahasa Regency

- Tax License of Lastari SMEs

- Location of Lastari SMEs

- Identity of Owner SMEs

- Family Card of the owner of Lastari SMEs

- Passport photos

- Lab Test Certificates in Baristan (Industrial Research and Standardization Center) for E-coli and Formalin.

- Sertificate of P-IRT given by North Minahasa District Health Office.

- Feasibility Test of Lastari Products by North Minahasa District Health Office.

- Stamp of Lastari SMEs

3.4.3. Lab Test Certificates in Baristan (Industrial Research and Standardization Center) for E-coli and Formalinfor Lastari SMEs at Kaima Village, District of Kauditan, North Minahasa Regency 
The Lab Test activity at the Research Institute and Industry Standardization is one of the important conditions for obtaining a license of product (P-IRT). Lab tests were conducted for Lastari SMEs, namely: Smoked Fish products (Cakalang Fufu) and Abon Cakalang products.

\subsubsection{Merk, Stamp and Product Packaging}

The stamp, label and packaging for the products produced by Lastari SMEs is a requirement for obtaining a license of product (P-IRT). Therefore, it has sought to make stamp, label and packaging of smoked fish products (Cakalang Fufu) and Abon Cakalang. This can be seen in the following Figure:

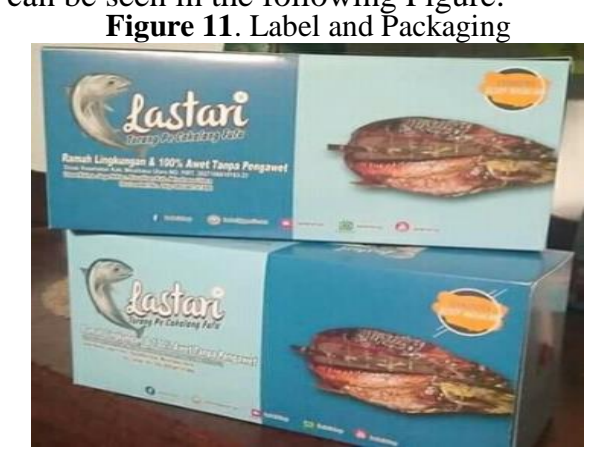

Figure 12. Label and Packaging of Abon
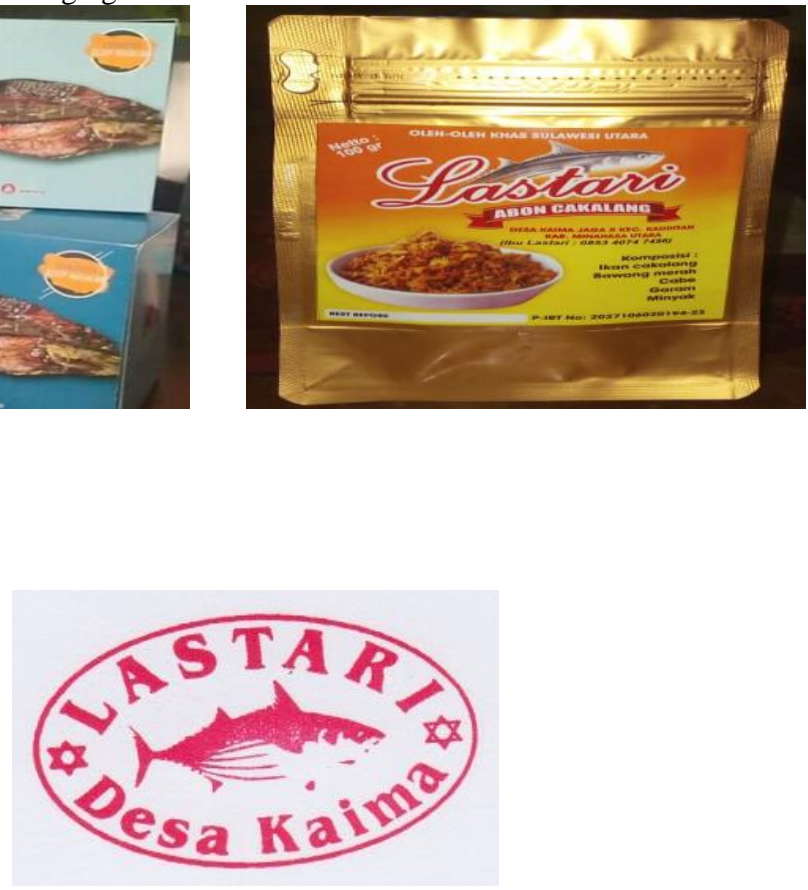

Figure 13. Stamp of Lastari SMEs

3.4.5. Workshop of Food Industry-Household Counseling (P-IRT) for Lastari SMEs, and Laiya SMEs, housewifes and Entrepreneurs in Kaima Village, Kauditan District, North Minahasa Regency

The workshop of P-IRT has been carried out at Kaima Village Hall with participants from housewifes and those who have businesses in Kaima Village. It also aims to help the community to have a product license or P-IRT certificate. 
Figure 14. Workshop activities of

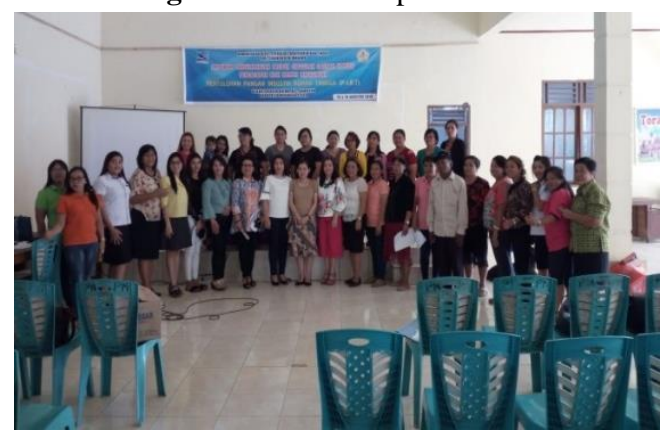

Figure 15. Activity of reliability test of

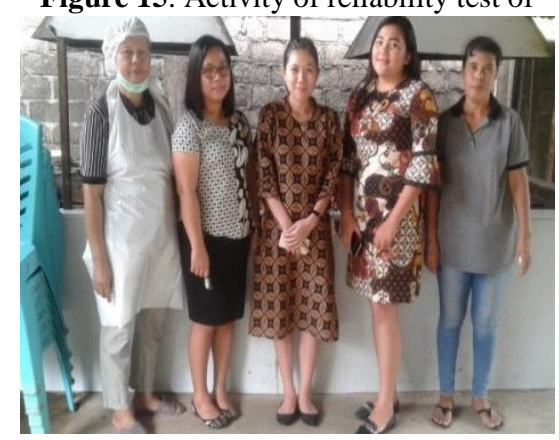

Workshop of Food and Household Industry has been carried out at Kaima Village Hall, Kauditan District with a total of 50 participants while the Product Feasibility Test was conducted at Lastari SMEs in Kaima Village. After the product feasibility test has been well assessed by the Health Service team, the Product Feasibility Test Team has given the license number (P-IRT number) as follows:

- Green Smoked Fish (Cakalang Fufu) of Lastari SMEs /P-IRT Number: 2027106010193 (Plastic Packaging and box)

- Abon Cakalang of Lastari SMEs /P-IRT Number: 5027106020194-23

(Aluminum packaging)

3.4.6. Provision of Food Recipes for 4 types of dishes that use Smoked Fish (Cakalang Fufu) with Japanese translation

Recently, Smoke fish products (Cakalang Fufu) sold in traditional markets and supermarkets are not equipped with recipes. Thus, people who come from outside of city of Manado who will provide souvenir for others find difficulty in processing it into a dish which tastes like what it be made by native Manado people.

Based on this background, this community activites is provided food recipes which is made from Smoked Fish (Cakalang Fufu), can be easily carried out and it will be included in packaging of Smoke Fish (Cakalang Fufu). It is also translated in Japanese and Video Recipes, namely in Manado language are: (1) Cakalang Fufu Rica-rica; (2) Cakalang Fufu Pampis ; (3) Cakalang Fufu Santang (mixed with coconut milk); and (4) KangkungTumisCakalang Fufu. The recipes of foods have been feasibility tested by the team as follows: 

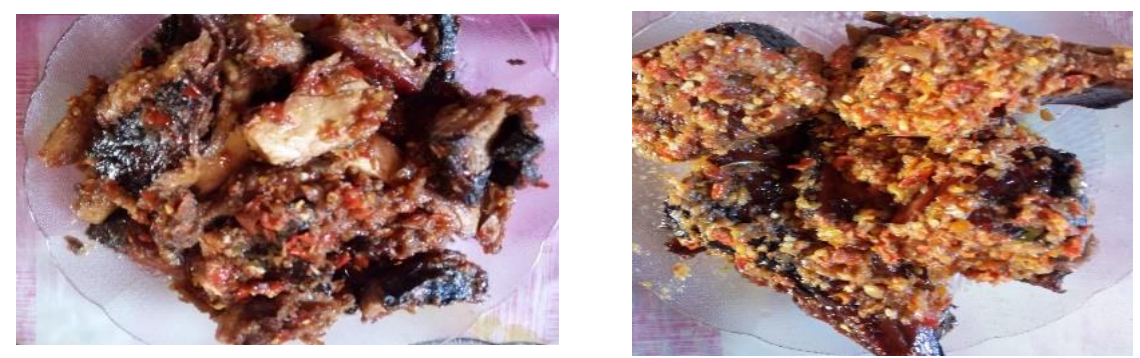

Figure 16. Cakalang FufuPampis

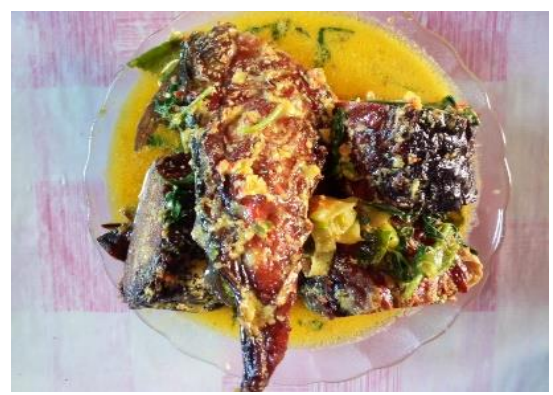

Figure 18. Cakalang Fufu Pampis
Figure 17. Cakalang Fufu Rica-Rica

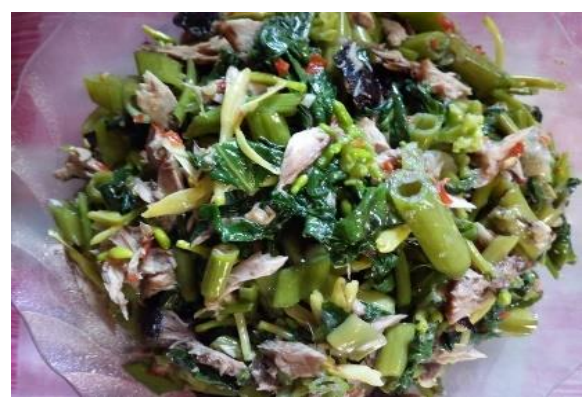

Figure 19. Sayur Kangkung Tumis Cakalang Fufu

Moreover, the recipes have been tested by the PPPUD team in 2 times. These recipes have also been translated into Japanese. These recipes will be included in the paper and plastic package, thus consumers can process the Smoked Fish (Cakalang Fufu) properly. The recipe test activities can be seen in the following figure: 

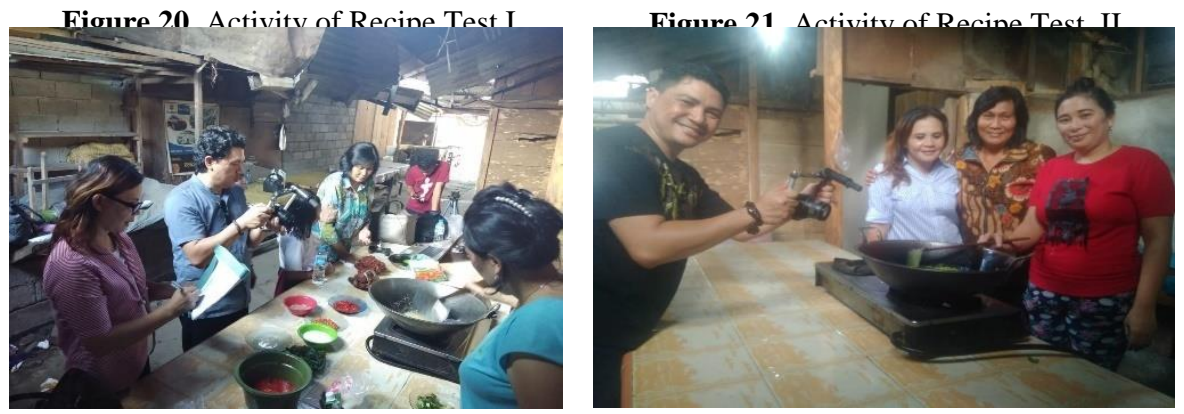

\subsubsection{Potential Custommer}

Potential customers have been contacted both in Bali and Malang. Restaurant operators totaling 4 restaurants in Bali and 1 restaurant in Malang have been willing to become Lastari SMEs customers. Recently, they only entrust Cakalang Fufu through relatives or families who brought from ManadoThisis due to the difficulty in finding producers who provide regular supply to their restaurants. Therefore, they requested that they be able to send the production process of Smoked Fish (Cakalang Fufu) produced by Lastari SMEs

\subsubsection{Delivery Services}

It was found by PPPUD team that delivery services through Cargo at Samratulangi Manado Airport can be categorized as cheaper compared to other shipping services.

\subsubsection{The involvement of students in the Business Management Study Program} Students of the Department of Business Administration, Business Management study program in Development Program of Regional Primer Product 2018 have been involved to form public opinion on Brand of Lastari Label. In addition, activities of 2017/2018 semester in the Project Business course, a group of students have chosen Abon Cakalang as their business activities guided by the team. They are able to form public opinion to build a Brand Image for the Lastari Brand by selling and making exhibitions at the end of the semester in the Business Project course. The student activities can be seen in the following Figure: 


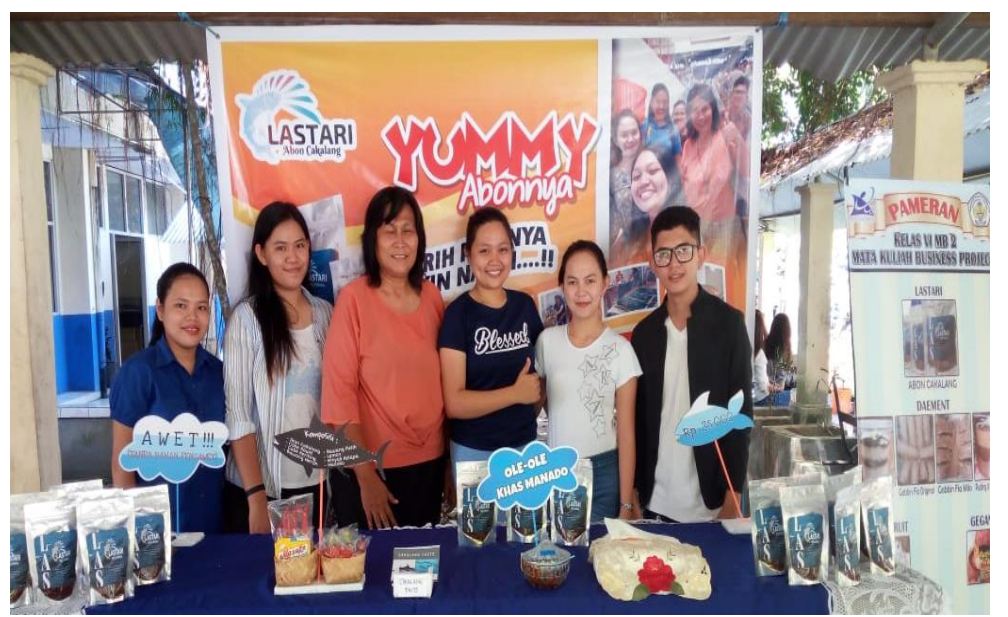

Figure 22. The activities of productexhitibition of Abon Cakalang by Group of Students Rama Lingkungan

Abon Cakalang cooking recipes used by students have been taught to Lastari SMEs. The existence of a potential market from the sale of Abon Cakalang which is shown from the results of the students' business activities. Therefore, the proposal of product license (P-IRT) can be carried out simultaneously at a lower cost. Thus, business diversification for Lastari SMEs in the future is: Abon Cakalang.

\section{Conclusion}

The activities of Development Program of Regional Primer Product have been well established between team, SME's Lastari, SME'sLaiya, the leader of the Business Administration Department, Mechanical Engineering Department, Electrical Engineering Department, Civil EngineeringDepartment, and lecturers in the implementation of PPPUD activities in accordance with the competencies in their respective fields. SME's Lastari and Laiya are very enthusiastic in carrying out this program for their business 
development. The stages of activities have been implemented according to the needs of each SMEs and the availability of budget. The production capacity has been increased with the availability of green-tech in production process, althoughthe installations for producing liquid smoked have not functioned properly as has been produced in the research in 2017. Therefore, product of green smoked fish cannot be introduced this year. The place arrangement in the production process has been found cleanliness, tidiness and comfortable. The availability of innovative packaging with the presence of recipes can be useful for customers (especially those who love to consume fish). The availability of business licenses for SME's Lastari and Laiya. Finally, there are some benefits for lecturers in enhancing knowledge and practicein developing the character of entrepreneurship for students, as well as an evaluation for curriculum development of business management department.

\section{References}

[1] Sundah DIE, Tawalujan L and Maramis. Pengembangan Bisnis Ikan Asap Ramah Lingkungan Bagi Kesejahteraan Nelayan Tradisional di Teluk Manado: Hasil Penelitian (2016).

[2] Sundah, D.I.E., Tawalujan, L., dan Maramis. Pengembangan Bisnis Ikan Asap Ramah Lingkungan Bagi Kesejahteraan Nelayan Tradisional di Teluk Manado. Hasil Penelitian, (2017).

[3] D I E Sundah et al. Developing entrepreneurial competencies for successful business model canvas. J. Phys.: Conf. Ser. 953012040 (2018).

[4] Sundah, D.I.E. Manajemen Sumber Daya Manusia. Pineleng, Manado: PercikanHati (2018).

[5] Schmidt J J, Soper J C, Bernaciak J. Creativity in the entrepreneurship program: a survey of the directors of awardwinning programs. Journal of Entrepreneurship Education. 16, 31 43 (2013).

[6] Mostafa M. Factors affecting organizational creativity and innovativeness in Egyptian business organizations: an empirical investigation, Journal of management development, 24, 1, pp. 7-33 (2005).

[7] Minello I F, Scherer L A and Alves L C. Entrepreneurial competencies and business failure, International Journal of Entrepreneurship, 18, pp. 1-15 (2014).

[8] Bae T J, Qian S, Miao C and Fiet J O. The relationship between entrepreneurship education and entrepreneurial intentions: a meta-analytic review, entrepreneurship theory and practice, 1042-2587 (2014).

[9] Tripopsakul S and Charupongsopon W. What skills do nascent entrepreneurs need? The evidence from Thailand, European Research Studies, XX, 2A, 250-263 (2017).

[10] Naser K, Mohammed W R and Nuseibeh R. Factors that affect women entrepreneurs: evidence from an emerging economy, International Journal of Organizational Analysis, 17,3, 225-247 (2009).

[11] Soomro B A, Shah N and Mangi S. Factors affecting the entrepreneurial leadership in small-and medium-sized enterprises (SMEs) of Pakistan: an emperical evidence, Word Journal of Entrepreneurship, Management and Sustainable Development, https://doi.org/10. 